\title{
Fishing selectivity as an instrument to reach management objectives in an ecosystem approach to fisheries
}

\author{
Fauconnet Laurence ${ }^{1,{ }^{*}}$, Rochet Marie-Joëlle ${ }^{1}$ \\ ${ }^{1}$ Ifremer, Unité Écologie et Modèles pour l'Halieutique, Rue de l'Ile d'Yeu, B.P. 21105, 44311 Nantes \\ CEDEX 03, France \\ *Corresponding autor : Laurence Fauconnet, email address : laurence.fauconnet@gmail.com
}

\begin{abstract}
:
With the development of the ecosystem approach to fisheries, improving fishing selectivity has increasingly been put forward as an objective for management. The aim of this paper is to clarify the limits of fishing selectivity and its use in fisheries management. Fishing selectivity would be better apprehended if restricted to the catching process only, not to the utilisation that is made of the catch once onboard, which falls under catch utilisation. Confusion would be further limited if fishing selectivity is restricted to the fishing operation scale, while exploitation pattern, i.e. the distribution of fishing mortality at the population or community level, applies to larger scales. Fishing selectively is minimizing bycatch - catching primarily the fishing trip targets. Since the ecological consequences of maximising the target catch relative to bycatch remain unknown at integrated scales, fishing selectivity cannot be used as an objective in itself. However, its small scale, high manageability and good understanding make it a convenient instrument to reach management objectives at large scales. Selectivity can serve to manage what is extracted from the ecosystem and thus what can be used, and/or to manage what is left in the ecosystem and how fishing impacts it. Different factors affect fishing selectivity, catch utilisation and exploitation patterns, some of them are manageable and thus can be used to move towards these objectives. Management tools are diverse, but need to be integrated to meet large-scale objectives. The complexity of dealing with large scales incurs a need to develop the available knowledge on exploitation patterns and catch utilisation to be able to adequately manage and monitor progress toward selectivity-related objectives.
\end{abstract}

\section{Highlights}

- We aim at clarifying the limits of selectivity and its use in fisheries management. Selective fishing cannot be used as management objective for scale reasons. Scales and perspectives are key elements in defining management objectives. Selectivity can be used to limit fishing impacts and/or optimise catch utilisation. 
Keywords: Catch-related processes, Catch utilisation, Exploitation pattern, Gear technology, Integrated scales, Management tools

\section{Introduction}

When fishers set out on a trip, they have specific targets in mind - the catch they intend to bring back. But when the gear is hauled there can be less, or more, or something else than the anticipated catch. Bycatch is the part of the catch that was unintended, which can then be retained and landed, or returned to the sea; discards are the returned part. Fishing selectively is minimizing bycatch and discards - catching primarily the trip targets. Improving the selectivity of fishing has been increasingly put forward as an objective of fisheries management, to address the unintended effects of fishing on non-target species, minimize waste, and improve the efficiency of fishing activities (Garcia et al., 2003; Pikitch et al., 2004; Worm et al., 2009; Dunn et al., 2011). The concern regarding the bycatch of rare and/or vulnerable species appeared on the public agenda as a result of a few highly publicised cases, such as dolphins caught in tuna purse-seine fisheries in the 1960s, and sea turtles in shrimp trawl fisheries (Hall et al., 2000). The concern regarding discards of more common species, 
either commercial or non-commercial, and the subsequent waste, arose soon after (Saila, 1983). However, recent debates have raised the point that ecosystem impacts are more than just the sum of impacts on ecosystem components - and that an uneven distribution of fishing pressure across ecosystem components might have broad scale unintended impacts as well (Garcia et al., 2012).

The enlargement of the fishing selectivity concept with the development of the ecosystem approach to fisheries has contributed to emphasize confusion and disagreement (Kennelly and Broadhurst, 2002; Garcia et al., 2012). Different dimensions, scales and processes are nowadays implied when examining which fishing activity is considered more or less selective. For example, is a fishing gear that only catches small individuals more selective than a gear that mainly catches large sized-individuals and some small ones? With regard to target or intention, the fishing activity can be viewed from two perspectives: the "positive" perspective intends to maximise the part of the catch that is wanted; the "negative" perspective to avoid or minimise the catch that is unwanted. "Wanted" and "unwanted" can both connect to different intentions or purposes - commercial, conservation, etc. This emphasizes an important aspect to be considered: the objectives aimed at by fishing activities. Those objectives are likely to differ from different stakeholders' perspectives. To limit confusion, Millar and Fryer (1999) distinguished different types of selectivity according to the population from which fish were selected from, highlighting the importance of the considered scale and perspective.

This paper proposes that the term fishing selectivity is most appropriate to the description of the catching process of fishing gear. As such, it should be restricted to the fishing operation scale. The concept of exploitation pattern describes the distribution of fishing mortality over the length or age composition of a population (ICES, 2014a). It is relevant for scales beyond the fishing operation. The concept of exploitation pattern can be extended to all community components. This enlarged concept would be referred to as community exploitation pattern. The concept of catch utilization is further defined to include the fate of the catch once onboard, whether it is kept and used, or discarded. Those three concepts describe catchrelated processes under different perspectives or scales. Fishing selectivity, as it determines what is caught, is central to both catch utilization and exploitation pattern, what makes it a convenient instrument to act upon them. Fishing selectivity cannot be set as an objective in itself, but can be used to reach management objectives at large scales. As fishing selectivity, catch utilization and exploitation pattern are closely linked, and even intermingled, the paper starts with definitions. The management objectives related to these processes relevant in an ecosystem approach to fisheries are then discussed. As a help for management to meet selectivity-related objectives, the factors affecting each process are then listed, emphasizing those which can be managed. The knowledge available to manage and monitor progress toward these objectives is finally contrasted across the three concepts.

\section{Definitions. A matter of scale and perspective.}

Fishing selectivity, catch utilization and exploitation pattern operate at different scales (Table 1) and in different dimensions of the socio-ecosystem, but they are closely related. Even if somehow artificial, splitting these highly entangled processes into three discrete concepts is a necessary construct for understanding and management purposes.

(Insert table 1) 


\subsection{Fishing selectivity restricted to the operational scale}

Fishing selectivity is the probability of catch resulting from the extraction of some individuals in the environment during the fishing operation. All fishing gears are somehow selective and catch individuals in species, length or age composition that differ from their actual composition in the environment (Wileman et al., 1996). Fishing selectivity is a measure of the gear selection process (Wileman et al., 1996). As such, it applies at the fishing operation scale (Table 1). Two components of fishing selectivity should be distinguished. Available selectivity quantifies the catching process of the individuals that were present in the path or the surroundings of the gear, but possibly avoided it (Fig.1 ; Millar and Fryer, 1999). The individuals that were not able to avoid the gear, came in contact with it where a second selection occurred. Contact selectivity quantifies the catch of those individuals that came in contact with the gear (Millar and Fryer, 1999).

\section{(Insert figure 1)}

Population selectivity had also been defined to quantify the catch of individuals from the whole population (Millar and Fryer, 1999; Sampson, 2014). It implies to integrate all catch processes accross the different gears occuring in a given fishing ground. The use of the term selectivity for such large scales considerations and integrated processes might lead to confusion and disagreement (Garcia et al., 2012). The use of another term appears relevant to better distinguish the scales and processes involved. Exploitation pattern as defined below is suggested.

\subsection{Exploitation pattern is the cumulative result of gear selectivities at large scales}

Exploitation pattern describes the distribution of fishing mortality across components of a population (ICES, 2014a). Exploitation pattern is the cumulative result of the fishing selectivity of all gears deployed at the population scale - generally, a large spatio-temporal scale, even if it can greatly vary from a small coastal population to a wide ocean pelagic population (Table 1). It takes account of how the different gear selectivities concur to determine which individuals are removed from the population, by further considering the availability of individuals to the different gears (Sampson, 2014 ; Fig. 1). By integrating fishing selectivity across all gears (or fisheries) that catch the population, the focus shifts from the catch to the population production and dynamics (Sampson, 2014). The population perspective raises questions related to yields and sustainability, thereby also enlarging the time scale considered. When scaling up to the community level, the community exploitation pattern combines population exploitation patterns of all species in a given area (Fig. 1). The change of organisation level entails a change of scale, towards longer time scales relevant to interspecific processes. Because the different populations which make up the community are likely to occupy different geographical ranges, at the community level the boundaries of the spatial area are somewhat arbitrary and need to be decided upon.

\subsection{Catch utilization refers to the fate of the catch once onboard}

Catch utilization is the result of the sorting process, i.e. the decicion of which parts of the catch are retained and thus landed, and which ones are discarded (Fig. 1). Unlike exploitation pattern, catch utilization does not directly include fishing selectivity, but depends on it. The more selective the fishing operation, the more the catch should be usable - a catch made up of the target only could be fully utilized. As a result, catch utilization is often perceived as a measure of fishing selectivity: high discard rates indicate poor selectivity. However, retention 
does not depend just on the catch, it is constrained by what can be kept onboard or not. Part of the bycatch, e.g. of high-value species, might be landed even if they were not initially targeted. It is even likely that some bycatch is expected by fishers in order to diversify their landings for markets. Conversely, part of the target catch is sometimes discarded, e.g. individuals that do not meet legal requirements such as minimum landing sizes, or legal-sized individuals that are discarded because they are damaged, or to save quota for larger individuals of higher value, a practice known as high-grading. The decisions made by the fishers while sorting take account of the whole trip, including achieved and expected catch, and the opportunities and constraints imposed by regulations and markets on a daily, seasonal, and annual basis (Eliasen et al., 2014). Therefore, catch utilization involves spatial and temporal scales larger than the fishing operation (Table 1).

\section{Which management objectives are contingent upon selectivity ?}

Fishing gears have been continuously adapted and modified to improve fishing selectivity. Today, gears that avoid the catch of undesirable species and sizes, i.e. display negative selectivity, while maximising the catch of commercial-sized individuals of the target species, i.e. with positive selectivity, are wanted. Technology and markets have been the main incentives to decide which components of the marine communities should be targeted (Hall et al., 2000). Targets were not decided based on ecological considerations, but they do affect the ecosystem. Fishing intention has a strong influence on catch profiles (Marchal, 2008), but the large-scale impacts of the combined catch profiles resulting from fishers targeting, i.e. selectivity, remain unknown. Thus, for scale reasons, maximizing the catch of targeted individuals, i.e. fishing more selectively, appears not relevant as a management objective. At large scales, exploitation pattern and catch utilization are more appropriate to define objectives.

\subsection{Conserving population / community structure and function}

Increased fishing selectivity can, for example, be implemented to reduce the catch of sea turtles in a fishery that overlaps with a population that is at risk of extirpation. In this example, the objective is to conserve this turtle population. Given the turtle ecology (wide distribution, long lifespan, etc.), it is a large-spatial scale and long-temporal scale objective. For doing so, fishing selectivity is adjusted to avoid catching turtles during fishing operations, which are fine-spatial and short-temporal scales, because given the turtle life history and the population status, even a single catch could be detrimental to the whole population. If the population was not at risk of extirpation, the catch of a turtle during a fishing operation, i.e. low selectivity, would not be detrimental in itself.

For more abundant and productive species, how to use fishing selectivity to conserve population is more complex. Historically, fisheries management focused on stocks of targeted species. To maintain the abundance and sustainability of a stock, fishing a narrow exploitation pattern at the population scale by avoiding juveniles and/or spawners has long been promoted (Armstrong et al, 1990). However, there are concerns that this could result in fishing-induced evolution such as earlier ages at maturity, faster growth rates (Conover, 2000; Law, 2007), or lower resilience to perturbations (Planque et al., 2010).

The ecosystem approach to fisheries aims at limiting environmental impacts of fishing activities (as phrased e.g. by European Union, 2013). At the community level, there is little knowledge of the consequences of community exploitation pattern, including whether it influences harvest sustainability. A narrow community exploitation pattern limited to targeted catches, is usually aimed at in order to limit collateral fishing mortality on other community 
components, the vulnerability of which is often unknown. However, only catching a restricted length range of a few target species might not be beneficial to the ecosystem (Zhou, 2008) and might even be at odds with the objective of protecting biodiversity (Zhou et al, 2010). The preferred extraction of some components such as predatory and/or large sized species could lead to temporal fluctuations in the length structure of marine communities and to changes in the trophic structure and functioning (Rochet et al., 2011; Rochet and Benoît, 2011; Garcia et al., 2012). A more balanced harvest, for example proportional to ecosystem production, has been suggested to be in better accordance with the ecosystem approach (Garcia et al., 2012). To date, model predictions of the consequences of balanced harvesting are nuanced and empirical evidence remains scarce and weak (ICES, 2014b). Given the difficulty to implement balanced fishing in practice, the discussion should be primarily seen as an incentive to think of exploitation patterns at the community level and their likely consequences (ICES, 2014b).

\subsection{Making the 'best' use of the catch}

Once the catch is onboard, one might aim at limiting the waste and using it all, or the most part of it, irrespective of the initial expectations. Fishers, consumers, conservationists and the general public may have different expectations from the catch. Fishers expect to optimise the species and length composition of the catch with respect to market demand and the fishing business efficiency. The lack of markets for many parts of the catch constitutes a major incentive to discard what does not match an established consumer demand. To reduce the work load of sorting the catch, fishers probably took early voluntary measures to limit bycatch, thereby improving fishing selectivity (Alverson et al., 1994). Expectations from the general public might be more related to the supply of food - including the supply of protein to ensure food security for a growing humanity (FAO et al., 2012) in an energy efficient manner (Garcia and Rosenberg, 2010). Reducing discards is aimed at because discards are often considered a waste of natural resources (Armstrong et al., 1990; Harrington et al., 2005). Even if it can greatly differ between gears and species, in many cases most individuals are dead when returned to sea (Suuronen, 2005; Broadhurst et al., 2006). Discarding is thus considered as generating unnecessary mortality of non-commercial species or juveniles of commercial species which, if they had not been caught, would have grown and could have been a valuable catch later on (Armstrong et al., 1990).

But discards are not necessarily lost to the ecosystem. First, even if discard mortality is believed to be generally significant (Suuronen, 2005; Broadhurst et al., 2006), some discarded individuals might be able to survive. Even if dead when returned to sea, discards were proven to benefit species such as seabirds (Votier et al., 2013) and benthic communities (Ramsay et al., 1997; Groenewold and Fonds, 2000). Simulations of an ecosystem model suggest that completely eliminating discards by landing all individuals that are currently discarded could cause trophic cascades, resulting in biomass reduction of several food web components such as carnivore and scavenging benthos, birds and mammals (Heath et al., 2014). Avoiding the unwanted catch in the first place, by improving fishing selectivity, could benefit to the ecosystem under heavy exploitation, but less so under light exploitation (Heath et al., 2014). The recycling of discards by marine ecosystems and their impact on food webs remain largely unknown, and require further research.

\section{Factors and management tools}

Different actors in the system can handle different tools (Fig. 2) to influence progress towards selectivity-related objectives. Fishers directly implement fishing selectivity, but the outcomes 
at the ecosystem and society levels also depend on many other factors, some of which can be managed.

(Insert figure 2)

\subsection{Many manageable factors at the Fishing Operation scale}

Fishing selectivity can be modified by (i) fishing gear technology, and (ii) the detailed settings of the fishing operation, which we designate as fishing tactic below. Developments in gear technology aim at improving gears by adapting their geometry, materials and the way they are rigged. Fishers decide on the target species or species group according to markets and the availability of resources in a given season and area, contingent on regulations. The most appropriate gear and its specifications are chosen to meet this target according to availability and behaviour, and technical regulations, such as minimum mesh size. Factors related to the fishing tactic such as time of day, fishing depth and duration are also adjusted appropriately. The combination of gear characteristics, fishers' tactics, and conditions of the fishing operation, including meteorological conditions, determine the species and size composition of the catch (Fig. 3).

\section{(Insert figure 3)}

Fishing selectivity depends on the interaction between the fish and the gear under the conditions of the fishing operation (Fig. 3). The factors affecting contact selectivity differ from those affecting available selectivity (Table 2). Contact selectivity mainly depends on the interaction between fish morphology and gear characteristics. Mesh size regulations are a much employed technical measure to let small fish escape once they contacted the gear, although their efficacy has been questioned (Halliday and Pinhorn, 2002). Selective devices and other approaches were developed to allow undesired species to escape from the gear once they contacted it, based either on their morphology, such as turtle excluder devices - grids which direct individuals larger than the bar spacing out of the gear (Hall et al., 2000), or on their behaviour, e.g. dorsal square mesh panels which let hake escape from Nephrops trawls thanks to their upward swimming behaviour (Graham and Ferro, 2004). Other selective devices are designed to prevent contact with the fishing gear, e.g. acoustic devices to repeal cetaceans (Gilman, 2011). The latter devices affect the available selectivity. Available selectivity primarily depends on the interaction between the behaviour of individuals in the area surrounding the gear and the way the gear is deployed. It can also be indirectly influenced by environmental factors affecting the swimming capacity of the fish, the gear motion and the detectability of the gear by the fish (Wardle, 1975, 1977; He, 1993; Table 2). Water turbidity, and mesh size and colour, for instance, influence the ability of fish to visually detect and avoid the gear (Wardle, 1993). In the case of towed gears, available selectivity is also affected by towing speed and duration as well as fish sustained and burst swimming capacity, and fish condition (Wardle, 1975, 1977).

\section{(Insert table 2)}

By contrast with the species-specific factors, such as morphology and behaviour, and the environmental conditions during fishing operations, all factors related to the gear and the fishing tactic are modifiable to some degree, thus manageable (Table 2). Many technical management tools are implemented to regulate fishing selectivity, many of which relate to gear characteristics (Table 3). Because fishers are the ones who ultimately decide about fishing selectivity, though under constraints of regulations and markets (Fig. 2), changes are more likely to be implemented when fishers are committed to the management measure (Kennelly and Broadhurst, 2002). Maintaining a high catch of commercial-sized individuals 
of the target species is, for example, an important condition to have good acceptance and use of novel or modified gears by professional fishers (Catchpole et al., 2005; Suuronen and Sardà, 2007).

(Insert table 3)

\subsection{Exploitation patterns further depend on large spatio-temporal dynamics}

Exploitation pattern is affected by all factors that modify fishing selectivity, added to factors of population availability to the different gears deployed in the fishing area (Table 2). Exploitation pattern depends on the interaction between population, or community, spatiotemporal dynamics and the fleet spatio-temporal dynamics. Fishing areas and seasons are key factors of exploitation patterns. In a given area at a given season, the targeted catch determines the combination of fishing gears deployed, and the fishing fleets' strategies, i.e. the combinations of fisher's tactics over the year. In a fish population, the spatio-temporal distribution of size and/or age groups depends, among others, on environmental conditions including tide, currents and water temperature, and fish ecology, e.g. reproductive and migratory behaviour (Fig. 3). The local aggregations of fish that are available to the gears may have length distributions that differ from the entire population (Millar and Fryer, 1999). At the community level, the same factors apply, but the combination of species in a given area at a given season and their interactions have to be considered (Table 2).

The factors related to natural population dynamics and communities cannot be managed. In contrast, fleet dynamics, especially fishing areas, seasons and the combination of gears deployed in the fishing ground are factors that can be managed. E.g. spatial and seasonal closures were shown to be effective management tools to maintain resources biodiversity and productivity (Cochrane, 2002). Regulations can also limit fishing capacity and effort (Table 3 ), but few technical tools aim at managing the combination of fishing activities. Fishing licences can be set to manage the number of vessels undertaking each metier, i.e. combination of gear and target species, but to date, little consideration has been given to the combination of metiers deployed on a given fishing ground.

\subsection{Catch utilization further depends on markets and regulations.}

Catch utilization depends on all factors influencing the sorting process (Fig. 3, Table 2). Economic incentives have been identified through interviews of fishers to be the main reason for discarding, especially for non-commercial species and species of low value (Arnason, 1994; Pascoe, 1997; Morandeau et al., 2014). In many cases, regulations such as quotas and minimum landing sizes can also be important reasons for discarding (Poos et al., 2010; Depestele et al., 2011). These factors are not independent, e.g. economic incentives operate under constraints of regulations. Quotas, for example, are a strong constraint in the economic strategy implemented by fishers to optimize their landings (Poos et al., 2010; Leleu et al., 2014). In the North Sea trawl fishery for instance, the small legal-sized individuals of plaice can be discarded in large quantities in order to save quotas for larger individuals with higher commercial value (Poos et al., 2010).

The volume and diversity of the catch, resulting from the gear selectivity, affect the duration and complexity of sorting (Fig. 3, Table 2). In purse seiners for example, if the catch is too diverse the entire haul is slipped, that is, released before being brought onboard. Time constraints and hold space limitations can also generate a significant part of the discards (Macher, 2008). The sorting behaviour of the crew also depends upon market constraints on 
quality, species-specific spoiling rates (Macher, 2008), meteorological conditions, crew size and experience, and sorting habits (Eliasen et al., 2014). Local social norms, social preferences and opinions about discarding practices were also reported to significantly affect the sorting process (Eliasen et al., 2014).

Catch utilization can be managed through selectivity, and/or regulations and markets. Full retention or banned retention of certain species and sizes, through controls on catch utilization, can create incentives for fishers to modify fishing selectivity. For example, a requirement that all tuna species caught by purse seine vessels were fully retained has been proposed to create an incentive for the vessels to avoid catching small sizes (Gilman, 2011). On the other hand, retention of at-risk shark species, such as thresher sharks, has been banned in several tuna fisheries worldwide with the aim to reduce the fishing mortality of these species (Gilman, 2011). Regulations can be directed at the landed part of the catch or at the total catch (Table 3). In many cases, landed-oriented regulations create obligations or incentives to discard ; while control and enforcement are more difficult and/or expensive for catch-oriented regulations (Sardà et al., 2015; Sigurðardóttir et al., 2015). Fisheries certifications and ecolabels are another tool to influence catch utilization through the market constraints (Fig. 2, Garcia et al., 2003).

\section{Understanding and monitoring}

Managing anything requires a minimum knowledge - understanding how management decisions are likely to affect the system and have the desired outcome; and monitoring progress towards the management objective(s). Knowledge availability greatly differs between fishing selectivity, exploitation patterns, and catch utilization.

\subsection{Best available knowledge for fishing selectivity}

To understand fishing selectivity, thorough knowledge on fish behaviour and on how gears catch fish is required. For estimating the available selectivity, comparison between individuals that were available to the gear and those that avoided it is necessary. The behaviour of fish in front of the gear can be observed through technologies ranging from simple camera systems to advanced acoustic systems, or a combination of both (Graham et al., 2004). For estimating the contact selectivity, comparison between the individuals that came in contact with the gear and those that escaped is necessary. For towed gears, it can be carried out using comparative or direct experiments, either by hauling simulteanously or alternatively a test and a control cod-ends (the latter retains "all" fish entering the cod-end), or by adding a small-mesh cover over the cod-end, which catches the individuals escaping through the meshes (Wileman et al., 1996; Millar and Fryer, 1999). The probability that a fish of a given length will be retained by the gear is often estimated through mathematical models (Wileman et al., 1996) and displayed as selection curves. The shape and width or slope of the selection curve inform on the gear selectivity (Fig. 4).

(Insert figure 4)

The relatively small, operational scale, and the long experience in gear technology explain the good knowledge on fishing selectivity, especially for contact selectivity for which direct observations can be carried out. This knowledge is not equal among species and gears though. For example, passive gear selectivity is less well known than trawl selectivity, and for most gears, there is no consensus on the most suitable shape of the selection curves. The knowledge on available selectivity is more limited, in particular for non-target species, because it relies on complex and indirect measurement methods. 


\subsection{High complexity for exploitation pattern}

To estimate population exploitation patterns, knowledge of the selectivity of all gears which target this population is necessary, but not sufficient. Spatio-temporal information on all catches and the population are also required. Such information is generally known for commercially important species that are analytically assessed (Harley and Myers, 2001), but not for non-target species (Jennings et al., 1999), even though several methods including length-cohort analysis and the swept-area method (Pope et al., 2000) and methods for Sustainability Assessment for Fishing Effects (SAFE; Zhou et al., 2011) were developed. At the community level, the complexity of dealing with several species and large scales makes some simplification necessary. Different approaches to aggregation have been used: by trophic level (Bundy et al., 2005), by functional group (Rochet et al, 2013) or by length or weight (Rochet and Benoît, 2011, Collie et al., 2013).

Characterizing exploitation patterns requires to describe the distribution of fishing mortality across components (whatever they be). To account for the whole fishing mortality, the indirect part, i.e. death, injuries or increased predation resulting from escapment or avoidance of the gear and ghost fishing, should also be estimated and added to catch mortality (Broadhurst et al., 2006). Only describing the catch, i.e. the direct part of fishing mortality, might not be an easy task, since estimating catch mortality requires to measure what was extracted with respect to what was present in the area. However, every observation method provides a different picture of community components, e.g. survey trawls have different catchabilities for each species (Fraser et al., 2007). Since no observation method is able to equally sample the whole community, the exact composition (in species, size, age, etc.) of marine communities remains unknown. So even if the catch composition can be integrated at the community level, it proves difficult to standardize with respect to what it was extracted from (Fauconnet et al., 2015).

\subsection{Knowledge is improving but still partial on catch utilization}

Knowledge of discarding has been developing only over the last two decades, in particular thanks to the development of onboard observer programmes, after the significance of the issue was highlighted (Alverson et al., 1994; Hall et al., 2000). Onboard observer programmes provide species and size composition of catches separated into landings and discards (Hall et al., 2000; Catchpole et al., 2011). Observer data also include information on the conditions of the trips and fishing operations, gear and targeted species, etc. (Wehrtmann and NielsenMuñoz, 2009; Dubé et al., 2012; Cornou et al., 2013). They provide a valuable source of data to characterize and quantify discards and thus to better estimate catch utilization. Landed or discarded fractions are common measures of catch utilization considered from different viewpoints. The landed fraction (landings divided by catches) describes the adequacy between what was caught and what was profitable to fishers or/and satisfied some consumer demand. The discarded fraction measures to what extent the catch was not used, or usable, for human purposes. These estimates are often associated with high uncertainty though because of high variability in discard practices, which is exacerbated by the limited fraction of the fishing activity that can be observed in many fisheries due to budget and human constraints (Borges et al., 2004; Uhlmann et al., 2013). Further, to better understand and manage catch utilization, discarded or landed fractions are not sufficient, a thorough investigation of the reasons for discarding is also necessary. Reasons for discarding have been only sporadically examined through interviews during (Morandeau et al., 2014) or after the sorting process (Arnason, 1994; Pascoe, 1997; Macher, 2008), or by inference from the catch composition (Catchpole et 
al., 2014). Such knowledge is often lacking, while it is essential to determine to which extent fishing selectivity can be adjusted to reduce discards.

\section{Conclusions}

"Improving selectivity" might not be as obvious an assignment as it may seem at first sight because improvements must be considered with respect to high-level, potentially conflicting objectives. Objectives are likely to vary according to different stakeholders' perspectives, and to the balance between consideration given to what is extracted from the ecosystem versus to what is left in it. If the aim is to limit fishing impacts, whether a more selective harvest constitutes an actual improvement depends on which impacts are considered: on target populations, bycatch species, or food web dynamics? If the aim is to limit waste, all costs and benefits need to be taken into account before equating waste with discards. There is also probably some trade-off between limiting fishing impacts and avoiding waste. Moreover, knowledge is limited with respect to both objectives, although it is developing. As for management tools, broadly speaking technical measures are relevant to fishing selectivity, effort regulation to exploitation patterns, and output regulations (catch or landings) and economic incentives to catch utilization. The toolbox is large and diverse, but to date there is little practical consideration of the combined use of such management tools towards largescale selectivity-related objectives.

\section{Acknowledgements}

Laurence Fauconnet received a PhD fellowship from the Région Pays de la Loire. Financial support was provided by the Direction des Pêches Maritime et de l'Aquaculture. The opinions expressed are those of the authors and do not necessarily reflect the views of the funding organizations. We thank Tom Catchpole and Verena Trenkel for useful comments on previous versions of this manuscript.

\section{References}

Alverson, D.L., Freeberg, M.H., Murawski, S.A., Pope, J.G. (1994) A global assessment of fisheries bycatch and discards. FAO Fisheries Technical Paper No. 339, 233 pp.

Armstrong, D.W., Ferro, R.S.T., MacLennan, D.N., Reeves, S.A. (1990) Gear selectivity and the conservation of fish. Journal of Fish Biology 37, 261-262.

Arnason, R. (1994) On catch discarding in fisheries. Marine Resource Economics 9, 189-207.

Borges, L., Zuur, A.F., Rogan, E., and Officer, R. (2004). Optimum sampling levels in discard sampling programs. Canadian Journal of Fisheries and Aquatic Sciences 61, 1918-1928. DOI: 10.1139/f04-138.

Broadhurst, M. K., Suuronen, P., Hulme, A. (2006) Estimating collateral mortality from towed fishing gear. Fish and Fisheries 7, 180-218.

Bundy, A., Fanning, P., Zwanenburg, K. (2005) Balancing exploitation and conservation of the eastern Scotian Shelf ecosystem: application of a 4D ecosystem exploitation index. ICES Journal of Marine Science 62, 503510. DOI: 10.1016/j.icesjms.2004.12.008.

Catchpole, T.L., Frid, C.L.J., Gray, T.S. (2005) Discards in North Sea fisheries: causes, consequences and solutions. Marine Policy 29, 421-430.

Catchpole, T.L., Enever, R., Maxwell, D.L., Armstrong, M.J., Reese, A., Revill, A.S. (2011) Constructing indices to detect temporal trends in discarding. Fisheries Research 107, 94-99. DOI: 10.1016/j.fishres.2010.10.012. 
Catchpole, T. L., Feekings, J. P., Madsen, N., Palialexis, A., Vassilopoulou, V., Valeiras, J., Garcia, T., Nikolic, N., Rochet, M.-J. (2014) Using inferred drivers of discarding behaviour to evaluate discard mitigation measures. ICES Journal of Marine Science 71, 1277-1285. DOI: 10.1093/icesjms/fst170.

Cochrane, K. L. (2002) A fishery manager's guidebook: management measures and their application. FAO Fisheries Technical Paper 424, FAO, Rome.

Collie, J., Rochet, M.-J., Bell, R. (2013) Rebuilding fish communities: the ghost of fisheries past and the virtue of patience. Ecological Applications 23, 374-391.

Conover, D. O. (2000) Darwinian fishery science. Marine Ecology Progress Series 208, 303-307.

Cornou, A.-S., Diméet, J., Tétard, A., Gaudou, O., Dubé, B., Fauconnet, L., Rochet, M.-J., (2013) Observations à bord des navires de pêche professionnelle - Bilan de l'échantillonnage 2012. Rapport Ifremer, 368 pp. http://archimer.ifremer.fr/doc/00167/27787/25978.pdf [In French.]

Depestele, J., Vandemaele, S., Vanhee, W., Polet, H., Torreele, E., Leirs, H., Vincx, M. (2011) Quantifying causes of discard variability: an indispensable assistance to discard estimation and a paramount need for policy measures. ICES Journal of Marine Science 68, 1719-1725. DOI: 10.1093/icesjms/fsr197.

Dubé, B., Diméet, J., Rochet, M.-J., Tétard, A., Gaudou, O., Messannot, C., Fauconnet, L., et al. (2012) Observations à bord des navires de pêche professionnelle - Bilan de l'échantillonnage 2011. Rapport Ifremer RBE/STH/LTBH No. 2012-008, 298 pp. http://archimer.ifremer.fr/doc/00109/21976/19586.pdf [In French.]

Dunn, D.C., Boustany, A.M., Halpin, P.N. (2011) Spatio-temporal management of fisheries to reduce by-catch and increase fishing selectivity. Fish and Fisheries 12, 110-119.

Eliasen, S.Q., Papadopoulou, K.-N., Vassilopoulou, V., Catchpole, T.L. (2014) Socio-economic and institutional incentives influencing fishers' behaviour in relation to fishing practices and discard. ICES Journal of Marine Science 71(5), 1298-1307. DOI: 10.1093/icesjms/fst120.

European Union. 2013. Regulation (EU) No 1380/201308 of the European Parliament and of the Council of 11 December 2013 on the Common Fisheries Policy, amending Council Regulations (EC) No 1954/2003 and (EC) No 1224/2009 and repealing Council Regulations (EC) No 2371/2002 and (EC) No 639/2004 and Council Decision 2004/585/EC. Official Journal of the European Union L 354:22-61.

FAO, WFP, IFAD (2012) The State of Food Insecurity in the World 2012. Economic growth is necessary but not sufficient to accelerate reduction of hunger and malnutrition. FAO, Rome. 65 pp.

Fauconnet, L., Trenkel, V.M., Morandeau, G., Caill-Milly, N., Rochet, M.-J. (2015) Characterizing catches taken by different gears from local fish communities as a step towards community pressure evaluation. Fisheries Research 164, 238-248. DOI: 10.1016/j.fishres.2014.11.019.

Fraser, H.M., Greenstreet, S.P., Piet, G.J. (2007) Taking account of catchability in groundfish survey trawls: implications for estimating demersal fish biomass. ICES Journal of Marine Science 64, 1800-1819.

Garcia, S.M., Zerbi, A., Aliaume, C., Do Chi, T., and Lasserre, G. (2003). The ecosystem approach to fisheries: issues, terminology, principles, institutional foundations, implementation and outlook. FAO Fisheries Technical Paper no. 443. FAO, Rome, 76 p.

Garcia, S.M., Kolding, J., Rice, J., Rochet, M.-J., Zhou, S., Arimoto, T., Beyer, et al. (2012) Reconsidering the Consequences of Selective Fisheries. Science 335, 1045-1047. DOI: 10.1126/science.1214594.

Garcia, S.M. and Rosenberg, A.A. (2010) Food security and marine capture fisheries: characteristics, trends, drivers and future perspectives. Philosophical Transactions of the Royal Society B: Biological Sciences 365 , 2869-2880. DOI: 10.1098/rstb.2010.0171.

Gilman, E.L. (2011) Bycatch governance and best practice mitigation technology in global tuna fisheries. Marine Policy 35, 590-609. DOI: 10.1016/j.marpol.2011.01.021. 
Graham, N., and Ferro, R.S.T. (2004). The Nephrops fisheries of the Northeast Atlantic and Mediterranean: a review and assessment of fishing gear design. ICES Cooperative Research Report no.270. ICES, Copenhagen, $40 \mathrm{p}$.

Graham, N., Jones, E., Reid, D. (2004) Review of technological advances for the study of fish behaviour in relation to demersal fishing trawls. ICES Journal of Marine Science 61, 1036-1043. DOI: 10.1016/j.icesjms.2004.06.006.

Groenewold, S. and Fonds, M. (2000) Effects on benthic scavengers of discards and damaged benthos produced by the beam-trawl fishery in the southern North Sea. ICES Journal of Marine Science 57, 1395-1406. DOI: 10.1006/jmsc.2000.0914.

Halliday, R.G. and Pinhorn, A.T. (2002) A review of the scientific and technical bases for policies on the capture of small fish in North Atlantic groundfish fisheries. Fisheries Research 57, 211-222.

Hall, M.A., Alverson, D.L., Metuzals, K.I. (2000) By-Catch: Problems and Solutions. Marine Pollution Bulletin 41, 204-219.

Harley, S.J. and Myers, R.A. (2001) Hierarchical Bayesian models of length-specific catchability of research trawl surveys. Canadian Journal of Fisheries and Aquatic Sciences 58, 1569-1584. DOI: 10.1139/cjfas-58-81569.

Harrington, J.M., Myers, R.A., Rosenberg, A.A. (2005) Wasted fishery resources: discarded by-catch in the USA. Fish and Fisheries 6, 350-361.

He, P. (1993) Swimming speeds of marine fish in relation to fishing gears. ICES Journal of Marine Science 196, 183-189.

Heath, M.R., Cook, R.M., Cameron, A.I., Morris, D.J., Speirs, D.C. (2014) Cascading ecological effects of eliminating fishery discards. Nature Communications 5:3893. DOI:10.1038/ncomms4893.

ICES (2014a) Glossary. ICES Website. http://www.ices.dk/pages/glossary.aspx (accessed 6.13.14).

ICES (2014b) Report of the Working Group on the Ecosystem Effects of Fishing Activities (WGECO). ICES CM 2014/ACOM:26, 174 pp.

Jennings, S., Greenstreet, S.P.R., Reynolds, J. (1999) Structural change in an exploited fish community: a consequence of differential fishing effects on species with contrasting life histories. Journal of Animal Ecology $68,617-627$.

Kennelly, S.J., and Broadhurst, M.K. (2002). By-catch begone: changes in the philosophy of fishing technology. Fish and Fisheries 3, 340-355.

Law, R. (2007) Fisheries-induced evolution: present status and future directions. Marine Ecology Progress Series 335, 271-277.

Leleu, K., Rochet, M.-J., Frangoudes, K., Ciolek, D. (2014) Document de restitution finale CarRejet: Caractérisation des Rejets en Mer. CNPMEM, 82 pp. http://archimer.ifremer.fr/doc/00190/30133/28596.pdf [In French.]

Macher, C. (2008) Productions jointes et mesures de gestion des pêcheries mixtes : application à la pêcherie chalutière langoustinière du golfe de Gascogne. $\mathrm{PhD}$ thesis, Université de Bretagne Occidentale, Brest, 401 pages. [In French.]

Marchal, P. (2008). A comparative analysis of métiers and catch profiles for some French demersal and pelagic fleets. ICES Journal of Marine Science 65, 674-686.

Millar, R.B. and Fryer, R.J. (1999) Estimating the size-selection curves of towed gears, traps, nets and hooks. Reviews in Fish Biology and Fisheries 9, 89-116. 
Morandeau, G., Macher, C., Sanchez, F., Bru, N., Fauconnet, L., Caill-Milly, N. (2014) Why do fishermen discard? Distribution and quantification of the causes of discards in the Southern Bay of Biscay passive gear fisheries. Marine Policy 48, 30-38. DOI: 10.1016/j.marpol.2014.02.022.

Pascoe, S. (1997) Bycatch management and the economics of discarding. FAO Fisheries Technical Paper No. $370,137 \mathrm{pp}$.

Pikitch, E.K., Santora, C., Babcock, E.A., Bakun, A., Bonfil, R., Conover, D.O., Dayton, P., et al. (2004) Ecosystem-based fishery management. Science 305, 346-347.

Planque, B., Fromentin, J.M., Cury, P., Drinkwater, K.F., Jennings, S., Perry, R.I., Kifani, S. (2010) How does fishing alter marine populations and ecosystems sensitivity to climate? Journal of Marine Systems 79, 403-417.

Poos, J.J., Bogaards, J.A., Quirijns, F.J., Gillis, D.M., Rijnsdorp, A.D. (2010) Individual quotas, fishing effort allocation, and over-quota discarding in mixed fisheries. ICES Journal of Marine Science 67, 323-333.

Pope, J., MacDonald, D.S., Daan, N., Reynolds, J., Jennings, S. (2000) Gauging the impact of fishing mortality on non-target species. ICES Journal of Marine Science 57, 689-696. DOI: 10.1006/jmsc.2000.0729.

Ramsay, K., Kaiser, M.J., Moore, P.G., Hugues, R.N. (1997) Consumption of Fisheries Discards by Benthic Scavengers: Utilization of Energy Subsidies in Different Marine Habitats. Journal of Animal Ecology 66, 884896.

Rochet, M.-J. and Benoit, E. (2011) Fishing destabilizes the biomass flow in the marine size spectrum. Proceedings of the Royal Society B: Biological Sciences 279, 284-292. DOI: 10.1098/rspb.2011.0893.

Rochet, M.-J., Collie, J.S., Jennings, S., Hall, S.J. (2011) Does selective fishing conserve community biodiversity? Predictions from a length-based multispecies model. Canadian Journal of Fisheries and Aquatic Sciences 68, 469-486. DOI: 10.1139/F10-159.

Rochet, M. J., Collie, J. S., Trenkel, V. M. (2013) How do fishing and environmental effects propagate among and within functional groups? Bulletin of Marine Science 89, 285-315. DOI: 10.5343/bms.2011.1138.

Saila, S.B. (1983) Importance and assessment of discards in commercial fisheries. FAO Fisheries Circular No. $765,62 \mathrm{pp}$.

Sampson, D.B. (2014) Fishery selection and its relevance to stock assessment and fishery management. Fisheries Research 158, 5-14. DOI: 10.1016/j.fishres.2013.10.004.

Sardà, F., Coll, M., Heymans, J.J., and Stergiou, K.I. (2015). Overlooked impacts and challenges of the new European discard ban. Fish and Fisheries 16, 175-180. DOI: 10.1111/faf.12060.

Sigurðardóttir, S., Stefánsdóttir, E.K., Condie, H., Margeirsson, S., Catchpole, T.L., Bellido, J.M., Eliasen, S.Q., Goñi, R., Madsen, N., Palialexis, A., et al. (2015). How can discards in European fisheries be mitigated? Strengths, weaknesses, opportunities and threats of potential mitigation methods. Marine Policy 51, $366-374$. DOI: 10.1016/j.marpol.2014.09.018.

Suuronen, P. (2005) Mortality of fish escaping trawl gears. FAO Fisheries Technical Paper No. 478. Rome, FAO. $72 \mathrm{p}$.

Suuronen, P. and Sardà, F. (2007) The role of technical measures in European fisheries management and how to make them work better. ICES Journal of Marine Science 64, 751-756.

Uhlmann, S.S., van Helmond, A.T.M., Kemp Stefansdottir, E., Sigurthardottir, S., Haralabous, J., Bellido, J.M., Carbonell, A., Catchpole, T., Damalas, D., Fauconnet, L., et al. (2014). Discarded fish in European waters: general patterns and contrasts. ICES Journal of Marine Science 71, 1235-1245. DOI: 10.1093/icesjms/fst030.

Votier, S.C., Bicknell, A., Cox, S.L., Scales, K.L., Patrick, S.C. (2013) A Bird's Eye View of Discard Reforms: Bird-Borne Cameras Reveal Seabird/Fishery Interactions. PLoS ONE 8, e57376. DOI: 10.1371/journal.pone.0057376. 
Wardle, C.S. (1975) Limit of fish swimming speed. Nature 255, 725-727.

Wardle, C.S. (1977) Effects of size on the swimming speeds of fish. In: Scale Effects in Animal Locomotion. Academic Press, New York, pp. 295-313.

Wardle, C.S. (1993). Fish Behaviour and Fishing Gear. In The Behaviour of Teleost Fishes, Edited by T.J. Pitcher. pp. 609-643.

Wehrtmann, I.S. and Nielsen-Muñoz, V. (2009) The deep water fishery along the Pacific coast of Costa Rica, Central America. Latin American Journal of Aquatic Research 37, 543-554. DOI: 10.3856/vol37-issue3-fulltext19.

Wileman, D.A., Ferro, R.S.T., Fonteyne, R., Millar, R.B. (1996) Manual of methods of measuring the selectivity of towed fishing gears. ICES Cooperative Research Report No. 215, 132 pp.

Worm, B., Hilborn, R., Baum, J.K., Branch, T.A., Collie, J.S., Costello, C., Fogarty, M.J., et al. (2009) Rebuilding Global Fisheries. Science 325, 578-585. DOI: 10.1126/science.1173146.

Zhou, S. (2008) Fishery by-catch and discards: a positive perspective from ecosystem-based fishery management. Fish and Fisheries 9, 308-315.

Zhou, S., A. D. M. Smith, A. E. Punt, A. J. Richardson, M. Gibbs, E. A. Fulton, S. Pascoe, C. Bulman, P. Bayliss, and K. Sainsbury. 2010. Ecosystem-based fisheries management requires a change to the selective fishing philosophy. Proceedings of the National Academy of Sciences of the United States of America 107:9485-9488. DOI: 10.1073/pnas.0912771107.

Zhou, S., Smith, A.D.M., Fuller, M. (2011) Quantitative ecological risk assessment for fishing effects on diverse non-target species in a multi-sector and multi-gear fishery. Fisheries Research 112, 168-178. DOI: 10.1016/j.fishres.2010.09.028. 
Table 1. Scales associated with the three concepts discussed in this paper.

\begin{tabular}{cccc}
\hline Scale & Fishing selectivity & Catch utilization & Exploitation pattern \\
\hline Spatial & gear swept/soak area & local to national to & region $\left(10^{3}-10^{6} \mathrm{~km}^{2}\right)$ \\
& $\left(10^{-3}-10^{-1} \mathrm{~km}^{2}\right)$ & global & \\
Temporal & hour - day & week - month & year - decade \\
Organisation & fishing operation & fishing sector & population / community \\
\hline
\end{tabular}


Table 2. Main factors affecting the concepts discussed in this paper. Manageable factors are marked by an asterix.

\begin{tabular}{|c|c|c|c|c|}
\hline \multirow{4}{*}{ Category } & \multicolumn{3}{|c|}{ Community exploitation pattern } & \multirow{4}{*}{ Catch utilization } \\
\hline & \multicolumn{3}{|c|}{ Population exploitation pattern } & \\
\hline & & \multicolumn{2}{|c|}{ Available fishing selectivity } & \\
\hline & & & $\begin{array}{l}\text { Contact fishing } \\
\text { selectivity }\end{array}$ & \\
\hline $\begin{array}{l}\text { Environ- } \\
\text { ment of } \\
\text { fishing } \\
\text { operations }\end{array}$ & $\begin{array}{l}\text { Area: habitat, seabed type, } \\
\text { currents; } \\
\text { Season: water temperature, } \\
\text { thermocline depth, light } \\
\text { level; } \\
\text { Tides, sea state } \\
\text { (affect presence of fish and } \\
\text { fishery dynamics) }\end{array}$ & $\begin{array}{l}\text { Thermocline } \\
\text { depth } \\
\text { (affects fish } \\
\text { vertical } \\
\text { distribution); } \\
\text { Seabed type } \\
\text { (affects gear } \\
\text { motion and } \\
\text { visibility); } \\
\text { Sea state } \\
\text { (affects gear } \\
\text { motion) }\end{array}$ & $\begin{array}{l}\text { Water } \\
\text { temperature } \\
\text { (affects } \\
\text { swimming } \\
\text { ability) }\end{array}$ & $\begin{array}{l}\text { Species } \\
\text { composition; } \\
\text { Year class; } \\
\text { Meteorological } \\
\text { conditions } \\
\text { (affect sorting } \\
\text { behaviour of crew) }\end{array}$ \\
\hline $\begin{array}{l}\text { Fisher's } \\
\text { tactic } *\end{array}$ & $\begin{array}{l}\text { Gear type; } \\
\text { Target species; } \\
\text { Fishing depth; } \\
\text { Fishing time }\end{array}$ & $\begin{array}{l}\text { Fishing } \\
\text { depth } \\
\text { (affects light } \\
\text { level and } \\
\text { gear } \\
\text { motion); } \\
\text { Fishing } \\
\text { duration or } \\
\text { soak time; } \\
\text { Towing } \\
\text { speed; } \\
\text { Bait type and } \\
\text { size }\end{array}$ & & $\begin{array}{l}\text { Crew size and } \\
\text { experience; } \\
\text { Sorting habits; } \\
\text { Vessel } \\
\text { characteristics } \\
\text { (including hold } \\
\text { capacity) }\end{array}$ \\
\hline Gear * & $\begin{array}{l}\text { Combination of gears, and } \\
\text { gear characteristics } \\
\text { deployed in the area }\end{array}$ & $\begin{array}{l}\text { Gear vertical } \\
\text { and } \\
\text { horizontal } \\
\text { opening; } \\
\text { Gear design }\end{array}$ & $\begin{array}{l}\text { Mesh size and } \\
\text { shape; } \\
\text { Selective } \\
\text { device; } \\
\text { Cod-end and } \\
\text { twine } \\
\text { characteristics; } \\
\text { Hauling } \\
\text { procedure; } \\
\text { Catch volume }\end{array}$ & $\begin{array}{l}\text { Gear efficiency: } \\
\text { catch volume and } \\
\text { diversity (affects } \\
\text { sorting behaviour of } \\
\text { crew) }\end{array}$ \\
\hline
\end{tabular}




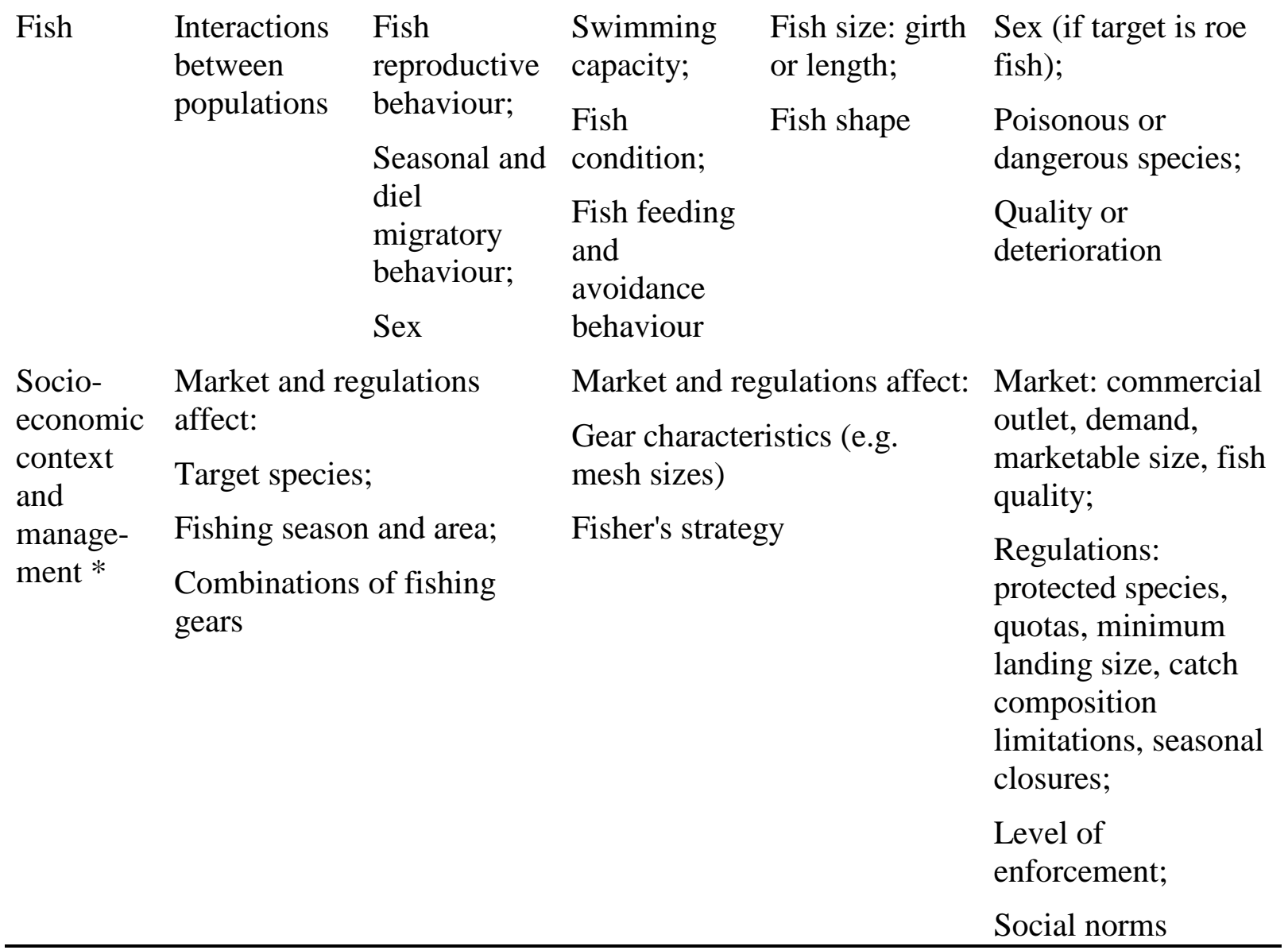

Table 3. List of technical management tools implemented to manage exploitation pattern, fishing selectivity and catch utilization.

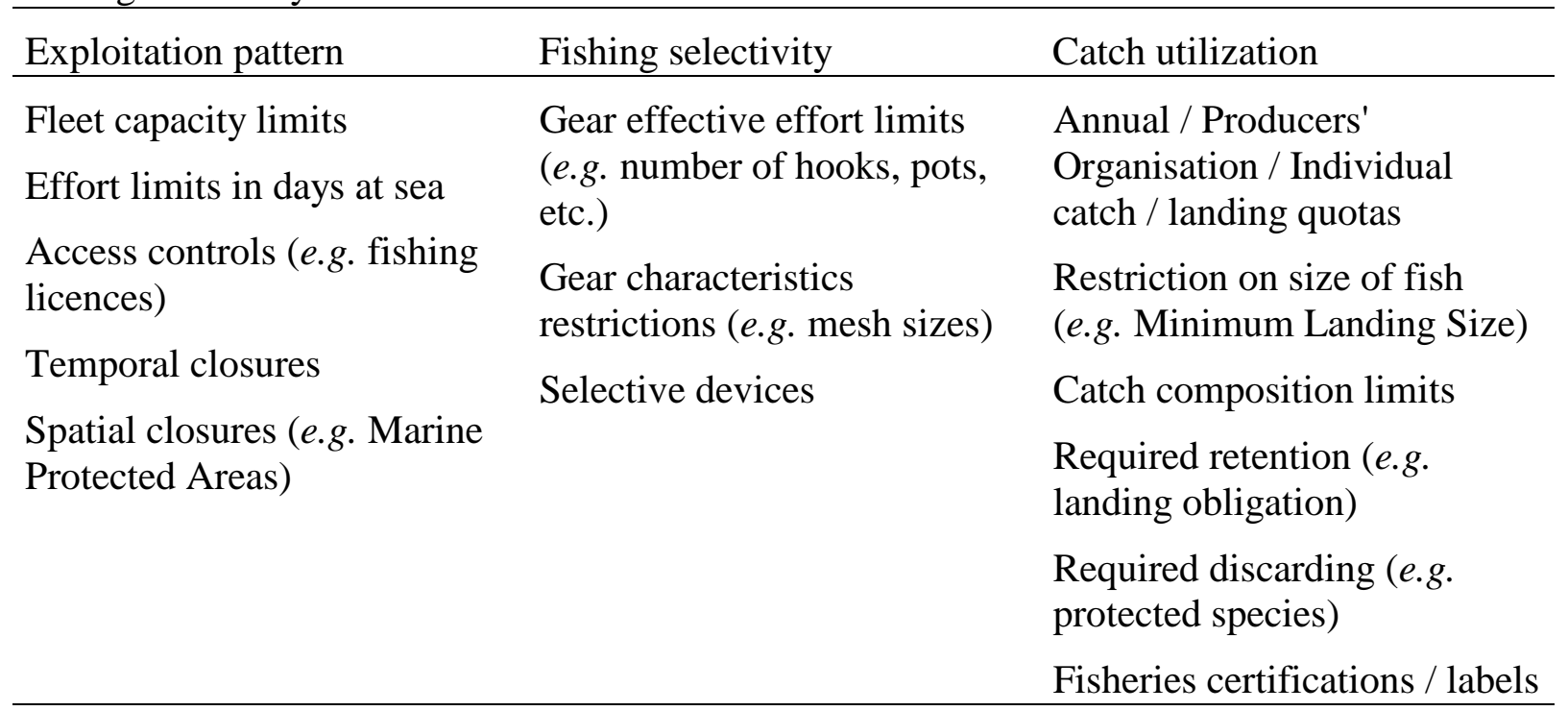


Figure 1. Schematic view of available and contact fishing selectivities, population and community exploitation patterns and catch utilization. The population exploitation pattern is only highlighted for population 1 (shaded area).

Figure 2. Schematic view of the natural and human parts of the socio-ecosystem, of their main actors or components and of their relationships pertaining to fishing selectivity (dark grey arrows), exploitation pattern (grey arrows) and catch utilization (light grey arrows) ; adapted from Garcia et al., 2003.

Figure 3. Main factors affecting fishing selectivity (underlined), catch utilization (bold) and exploitation patterns (italicized). Links between factors are distinguished between direct links (full arrows) and influencial links (dashed arrows). FO stands for fishing operation.

Figure 4. Schematic selection curves for (a) gears with maximum retention for the largest lengths, such as trawls and pots and (b) gears with retention restricted to intermediate lengths, such as gillnets and trammel nets. Three levels of sharpness or width of fishing selectivity are displayed, with sharp/narrow selectivity (black), medium (dark grey), and smooth/wide selectivity (light grey). 
Figure 1.

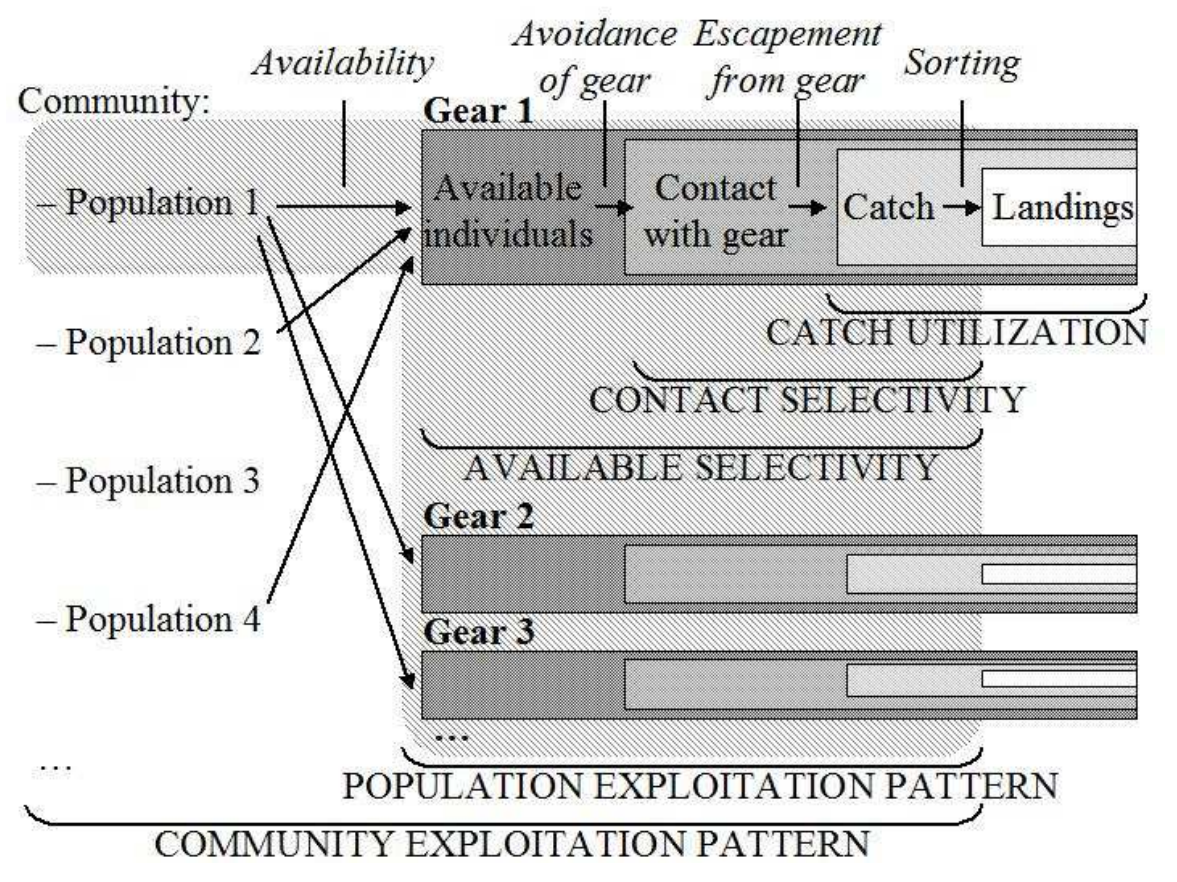

Figure 2.

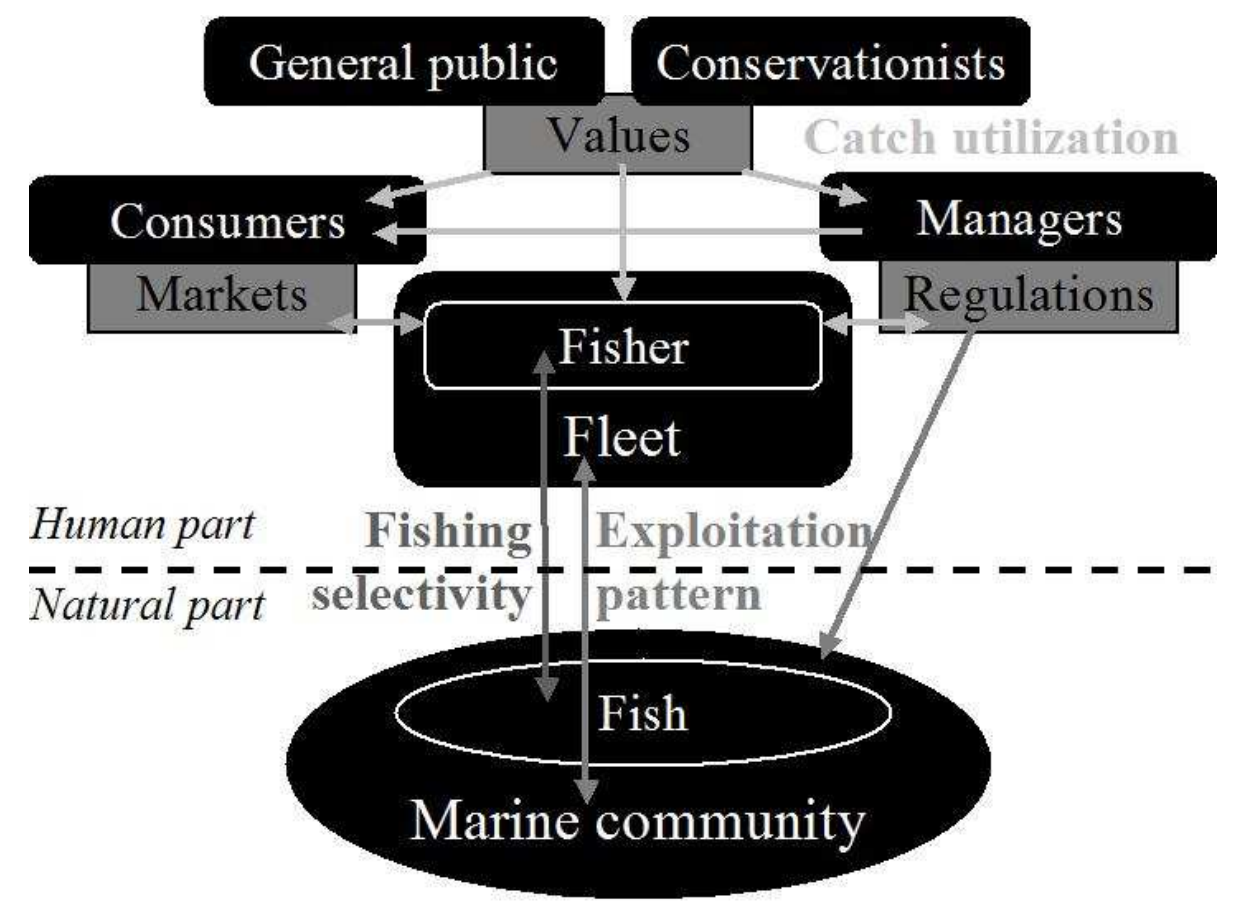


Figure 3.

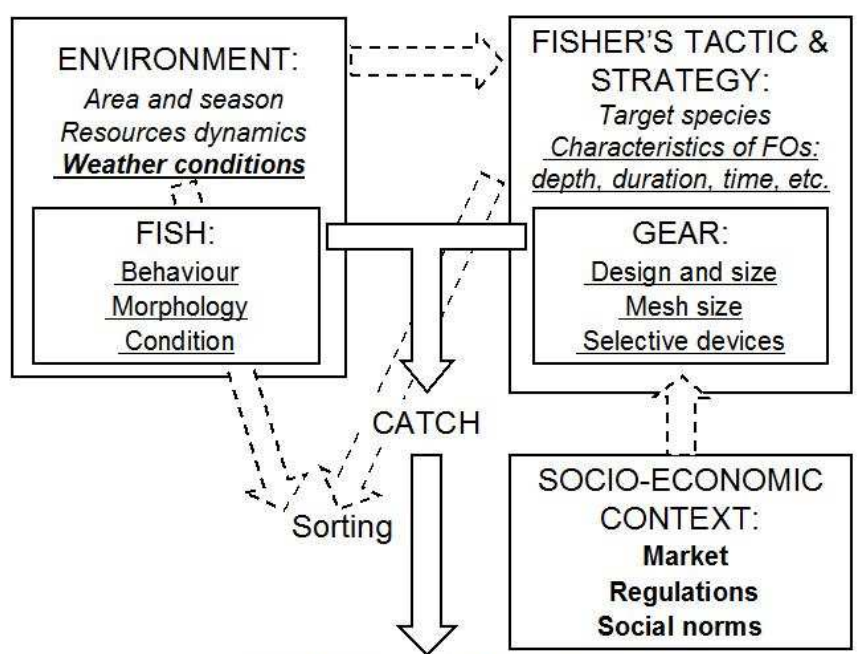

DISCARDS or LANDINGS

Figure 4.
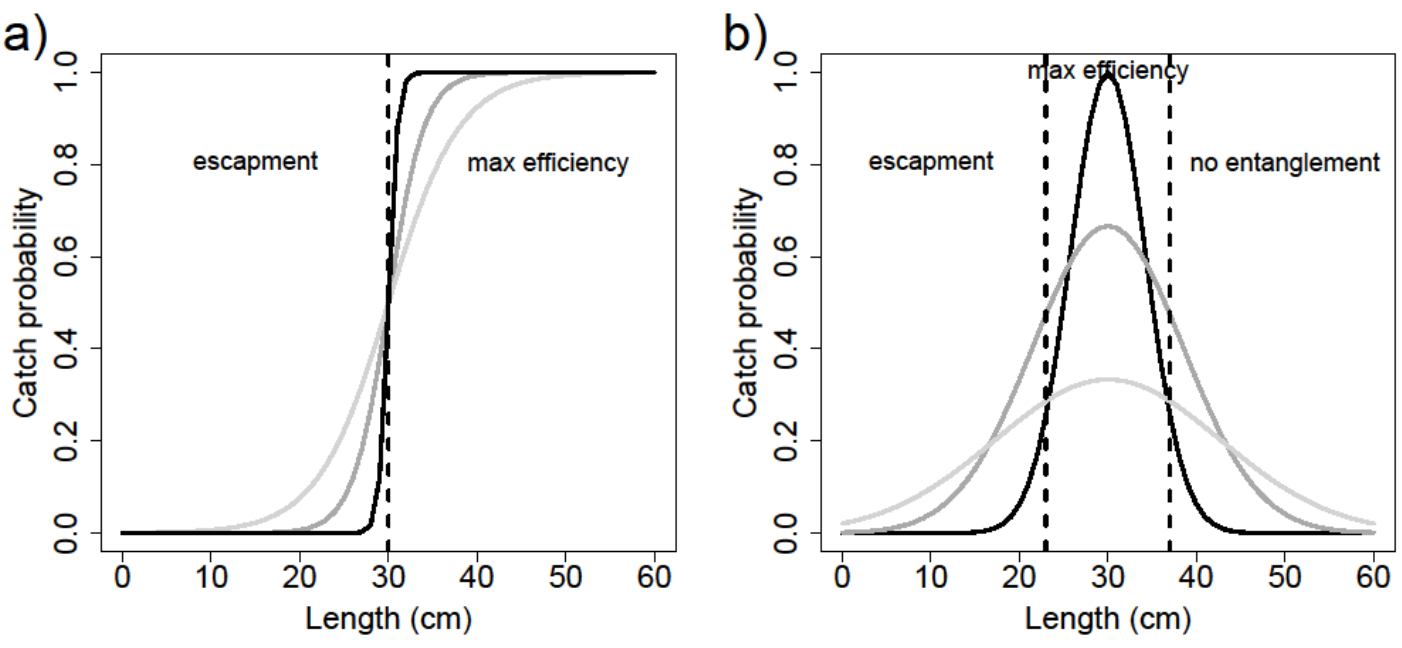